\title{
Assessment of management and basic beef quality assurance practices on Idaho dairies
}

\author{
J. B. Glaze Jr. ${ }^{1}$ and M. Chahine \\ Department of Animal and Veterinary Science, University of Idaho, Twin Falls Research and Extension Center, Twin Falls 83303
}

\begin{abstract}
In 2004 a mail-in survey was conducted to establish a baseline level of awareness and knowledge related to dairy beef quality assurance (BQA) issues in Idaho. A 30-question survey was mailed to every $(\mathrm{n}=736)$ registered Idaho dairy. Two-hundred seventy-three $(37 \%)$ dairies participated and were categorized as small ( $\mathrm{n}<201$ cows; 53.5\%), medium-sized ( $\mathrm{n}=201$ to 1,000 cows; $27.1 \%$ ) or large ( $\mathrm{n}>1,000$ cows; $19.4 \%$ ). The majority of respondents were dairy owners (83\%). Eighty-nine percent of respondents indicated they followed BQA recommendations for animal care. The neck region in cows was used by $68 \%$ of respondents for i.m. injections and by $80 \%$ for s.c. injections. In calves, the values were 61 and $78 \%$, respectively. Seventy-four percent of respondents indicated they had been trained for injections. Training methods cited included veterinarians $(19.8 \%)$, dairy owners $(16.8 \%)$, experience $(9.9 \%)$, and BQA events or schools (4.5\%). The importance of BQA in the dairy industry was rated 2.6 on a 5 -point scale $(0=$ low; $4=$ high $)$. Participants rated the effect of dairy animals on the beef industry at 2.5. Plastic ear tags were the preferred method of animal identification, with $100 \%$ of large dairies, $97.3 \%$ of medium-sized dairies, and $84 \%$ of small dairies citing their use. Less than $10 \%$ used electronic identification for their animals. Almost half (48\%) of large and medium-sized (49\%) dairies and $32 \%$ of small dairies supported a national animal identification program. A mandatory identification program was supported by 41,69 , and $59 \%$ for small, medium-sized, and large dairies, respectively. The percentage of dairies keeping records was similar between small (93\%), medium-sized (99\%), and large (100\%) dairies. Most small dairies (58\%) used some form of paper records, whereas most medium-sized $(85 \%)$ and large $(100 \%)$ dairies used computers for record keeping. The preferred method to market cull cows by Idaho dairies was the auction market (64\%), followed by order buyers (17\%), direct to the packer
\end{abstract}

Received March 18, 2008.

Accepted November 5, 2008.

${ }^{1}$ Corresponding author: bglaze@uidaho.edu
(17\%), private treaty sales (16\%), and forward contracts (1\%). To market calves, dairies used private treaty sales $(52 \%)$, auction markets $(42 \%)$, order buyers $(14 \%)$, and forward contracts (1\%). The results of this study will be used by University of Idaho Extension faculty in the design, development, and delivery of dairy BQA program information and materials.

Key words: beef quality assurance, dairy cow, survey

\section{INTRODUCTION}

Consumers today expect each food product they buy to be safe, wholesome, high quality, and consistent. In the marketplace, consumers have a variety of protein sources from which to choose. The beef industry found it necessary to address and eliminate quality and consistency shortfalls to maintain consumer demand for beef. A major component of this effort is beef quality assurance (BQA) educational programs. Beef quality assurance is a program designed to ensure that dairy and beef cattle are produced in a manner that results in safe, wholesome, high-quality, and consistent beef and beef products for consumers. Beef quality assurance is designed to enhance carcass quality by preventing residues, pathogen contamination, and carcass defects such as injection-site blemishes and bruises. Beef quality assurance educational materials are based on recommended national guidelines, best management practices, and results of scientific research.

The major and most recognized product produced by dairies is milk. Still, one product from dairies that is often overlooked, or disregarded, is beef. Market animals, such as cull cows and bulls, go directly from the producer (dairy or beef) to the packer. In 1994 it was estimated (Smith et al., 1994) that dairy cows accounted for approximately $8 \%$ of US domestic beef production, $25 \%$ of US market animal beef, and approximately $18 \%$ of US ground beef.

In 2005 there were 455,000 lactating cows on Idaho dairies (USDA-NASS, 2006). According to 2005 Idaho DHIA records, 30 to $35 \%$ of these cows left the herd and were destined for beef markets. This resulted in 136,500 to 159,250 Idaho dairy cows being harvested 
and sold as beef and beef products. Results of the 1999 National Market Cow and Bull Quality Audit (Roeber et al., 2000) indicated that beef quality shortfalls and inconsistencies cost the beef and cattle industries $\$ 68.82$ for every market cow and bull (dairy and beef) marketed in the United States. Considering the number of dairy cows marketed in Idaho, the potential cost to Idaho's beef industry was estimated to exceed $\$ 9$ million dollars.

Idaho's BQA program is administered and offered by University of Idaho Extension. A wide variety of educational materials is available and directed toward the Idaho beef industry. The program is supported by funds provided by the Idaho Beef Council. Traditionally, Idaho dairy owners, managers, and workers received little information or education on methods to improve the quality and value of their market dairy cows. The objective was to assess the awareness, knowledge, understanding, and implementation of BQA principles and practices on Idaho dairies. Additionally, the survey provided the opportunity to gain information on a variety of topics related to the Idaho dairy industry including demographics, employee resources, animal identification, record keeping, culling decisions, and cull cow and calf marketing options.

\section{MATERIALS AND METHODS}

The survey was designed to assess the understanding and utilization of BQA-friendly practices on Idaho dairies. University of Idaho Extension beef and dairy specialists compiled a preliminary list of questions for the survey. A draft questionnaire was reviewed by University of Idaho personnel, extension specialists and educators, and teaching and research faculty, and feedback was incorporated into the final version. Questions were selected based on their value in potential development and direction of future educational programming in dairy BQA and dairy management. The final survey consisted of 30 questions and was mailed to all dairy operations in the state $(\mathrm{n}=736)$. This list of dairies was generated from information on permitted dairies supplied by the Idaho State Department of Agriculture (ISDA). The list was cross-checked against information provided by the United Dairymen of Idaho. Questions on the survey were a mix of open- and closed-ended questions with multiple choices where applicable. Surveys were coded in a manner that allowed responses from individual dairies to be tracked. The list linking responses to individual dairies was maintained by a third party during data solicitation and was destroyed at the end of the study. The survey protocol used was approved by the University of Idaho Human Assurances Committee (\#06-229).
Following a protocol outlined by Dillman (1978), an initial survey, cover letter, and postage-paid return envelope were mailed to dairies by first-class postage on July 1, 2004. A postcard reminder was sent $30 \mathrm{~d}$ after the initial mailing to dairies that had not yet responded. At $30 \mathrm{~d}$ subsequent to the postcard reminder, a second survey form, cover letter, and postage-paid return envelope were mailed to dairies that had not responded to the initial questionnaire form. All data returned were entered into a spreadsheet and forwarded to the Social Science Research Unit at the University of Idaho, who conducted the analyses with SAS Version 9.1 (SAS Inst., Inc., Cary, NC).

Because many of the questions were of the format "mark all that apply," the following method was used for analysis. For each question, or choice within a question, answers were coded as " 1 " if the respondent marked that choice and a " 0 " if the respondent did not mark the choice. Entire questions were coded as missing (i.e., item nonresponse) if the respondent did not mark any of the choices for the question. Item nonresponse ranged from 0 to $13 \%$ for questions in which all respondents were expected to answer, but most commonly fell below $5 \%$.

Dairies were categorized based on current herd size. Herd size categories were small $(<201$ lactating cows), medium (201 to 1,000 lactating cows), and large $(>1,000$ lactating cows). The data gathered were categorical. The PROC SURVEYMEANS of SAS was utilized to produce estimates of survey proportion in each category or level. Evaluation of the dairy size effects was then performed using a generalized linear model (PROC GENMOD of SAS). Differences among groups were tested using the least significant differences. Some participants chose not to answer all the questions; thus, the reported percentage was the percentage response to the individual question. Some questions allowed several answers, and, thus, data might not add to $100 \%$.

\section{RESULTS AND DISCUSSION}

Of the 736 surveys that were mailed to Idaho registered dairy producers, 273 were returned, for a response rate of $36.9 \%$. This response rate was greater than those from a survey conducted by Buttars et al. (2006) for dairies in the Intermountain region of the United States, where response rates ranged from 13 to $29 \%$ ( $26 \%$ by Idaho dairy farmers). Additionally, the response rate was greater than the response rate $(28.7 \%)$ of a survey conducted by Payne et al. (1999) in which California dairy industry participants were asked about their interest in implementing a quality assurance program. Rogers et al. (2004) conducted a survey assessing the management decisions to improve beef 
Table 1. Location of routine i.m. injections in cows on Idaho dairies

\begin{tabular}{llccccc}
\hline Dairy size $^{1}$ & $\begin{array}{c}\text { Neck } \\
(\%)\end{array}$ & $\begin{array}{c}\text { Shoulder } \\
(\%)\end{array}$ & $\begin{array}{c}\text { Upper rear } \\
\text { leg }(\%)\end{array}$ & $\begin{array}{c}\text { Side or } \\
\text { ribs }(\%)\end{array}$ & $\begin{array}{c}\text { Lower rear } \\
\text { leg }(\%)\end{array}$ & $\begin{array}{c}\text { Tail-head } \\
(\%)\end{array}$ \\
\hline Small $(\mathrm{n}=139)$ & $64.0^{\mathrm{a}}$ & 10.0 & 31.7 & 3.6 & 7.9 & 18.7 \\
Medium $(\mathrm{n}=74)$ & $64.9^{\mathrm{a}}$ & 14.9 & 29.7 & 2.7 & 14.9 & 13.5 \\
Large $(\mathrm{n}=54)$ & $87.0^{\mathrm{b}}$ & 11.1 & 18.5 & 0.0 & 13.0 & 22.2 \\
\hline
\end{tabular}

${ }^{\mathrm{a}, \mathrm{b}}$ Values in columns with different superscripts differ $(P<0.05)$.

${ }^{1}$ Small $=<201$ cows; medium $=201$ to 1,000 cows; large $=>1,000$ cows.

quality of market cows from New Mexico dairies. They reported a response rate of $31 \%$. It should be noted that it is highly likely that some of Idaho dairy owners who responded to our survey own several dairies. If an owner returned one survey meant to report on several dairies, it is difficult to tell from the responses whether the owner was reporting on the total number of cows at all their dairies, or the average number of cows at each dairy. The analysis conducted here assumed the former, which could affect the skewness of the distribution. If an owner did respond for multiple dairies, the response rate was actually higher than reported and nonresponse was less of an issue.

To obtain basic information about Idaho dairies, the survey included questions about operation leadership, dairy size, and location. The majority of individuals completing and returning the surveys were dairy owners (83\%), followed by dairy managers $(5 \%)$. Twelve percent of the responses came from individuals who listed multiple positions at the dairy, one of which was owner. Some variation among dairy size classes was detected. Eighty-eight percent of respondents from small dairies were owners compared with 83 and $67 \%$ for mediumsized and large dairies, respectively. Sixteen percent of respondents from large dairies identified themselves as managers.

The largest number of survey participants represented small (146 or $53.5 \%$ ) dairies followed by medium-sized (74 or $27.1 \%$ ) and large (53 or 19.4\%) dairies. Small dairies averaged 92.7 cows, medium-sized dairies averaged 493.6 cows, and large dairies averaged 2,633.1 cows. Overall, the average number of cows was 710.5. This is slightly higher than the average number of cows per dairy (625.8) reported by ISDA (USDA-NASS, 2006).

To gain some understanding of the amount of employee resources that were used on Idaho dairies, respondents were asked to provide the number of employees that work directly with dairy animals. Small dairies had the fewest number of employees and large dairies had the largest number of employees. Small dairies averaged 1.9 employees, followed by medium-sized dairies with 5.4 employees and large dairies with 21.5 employees. On small dairies there were 48.8 cows per employee, where- as on medium-sized and large dairies there were 91.4 and 122 cows per employee, respectively. This increase in the number of cows per employee may indicate a greater level of efficiency on the larger dairies. Many of the large dairies were new and equipped with the latest technologies. These large dairies have the resources and opportunities to provide, or send workers to, trainings that allowed them to make the most of the technologies.

Beef quality assurance definitions, practices, and recommendations were not included on the survey or any correspondence materials. Dairy producers' knowledge and perceptions of BQA came from previous exposure to the issue. When asked if BQA recommendations were used during animal care activities, $89 \%$ indicated that BQA recommendations were followed on their dairies. These responses may lead to the belief that survey respondents knew what BQA was and what BQA-friendly practices entailed. Nonetheless, this was contrary to the injection site location results presented in Tables 1, 2, 3, and 4. With the neck region being the only BQA-friendly injection location, only 59 to $87 \%$ of respondents indicated use of the neck region for s.c. and i.m. injections in cows and calves.

Several questions were included to gain an understanding of injection procedures and practices. Tables 1 to 4 include the locations for routine i.m. and s.c. injections for cows and calves. The percentage of large dairies (87\%; Table 1) using the neck for i.m. injections in cows was greater than the percentage of mediumsized $(64.9 \%)$ or small dairies $(64.0 \%)$. Overall, the neck region was used by $68 \%$ of dairies for i.m. injections and by $80 \%$ of dairies for s.c. injections in cows. In calves, the values were 61 and $78 \%$, respectively. The use of the neck region by Idaho dairies for i.m. and s.c. injections was greater than the percentages reported for Pennsylvania dairies (Tozer et al., 2005). In that study, the majority (65\%) of injections in cows were given in locations other than the neck. The differences between these studies may be attributed to Idaho having a greater percentage of large dairies than Pennsylvania. The larger dairies may have greater resources and opportunities to send workers to training sessions that teach BQA-friendly practices. The large 
Table 2. Location of routine s.c. injections in cows on Idaho dairies

\begin{tabular}{lcccccc}
\hline Dairy size $^{1}$ & $\begin{array}{c}\text { Neck } \\
(\%)\end{array}$ & $\begin{array}{c}\text { Shoulder } \\
(\%)\end{array}$ & $\begin{array}{c}\text { Upper rear } \\
\text { leg }(\%)\end{array}$ & $\begin{array}{c}\text { Side or } \\
\text { ribs }(\%)\end{array}$ & $\begin{array}{c}\text { Lower rear } \\
\text { leg }(\%)\end{array}$ & $\begin{array}{c}\text { Tail-head } \\
(\%)\end{array}$ \\
\hline Small $(\mathrm{n}=139)$ & 75.5 & 12.9 & 6.5 & 5.8 & 2.9 & 12.2 \\
Medium $(\mathrm{n}=74)$ & 79.7 & 13.5 & 5.4 & 10.8 & 2.7 & 6.8 \\
Large $(\mathrm{n}=54)$ & 87.0 & 7.4 & 5.6 & 0.0 & 1.9 & 20.4 \\
\hline
\end{tabular}

${ }^{1}$ Small $=<201$ cows; medium $=201$ to 1,000 cows; large $=>1,000$ cows.

dairies may have more opportunities to offer training sessions on-site.

The survey asked if individuals giving injections were trained to do so. The percentage of trained workers on large dairies (92.3\%; Table 5) was greater than the percentage of trained workers on small dairies (75.8\%). The percentage of trained workers on large dairies was similar to the percentage of workers trained $(90 \%)$ in the administration of drugs reported by Payne et al. (1999). The differences in training in the current study may be due in part to the greater resources of large dairies and the ability of large dairies to send some workers to trainings, while others remained at work. Training methods varied. Of the respondents that identified a training method, $19.8 \%$ received training from a veterinarian, $16.8 \%$ received training from the owner of the dairy, $9.9 \%$ received on-the-job training (experience), $4.5 \%$ received training in a school or BQA event, and $3.5 \%$ received training from other sources. Overall, $45 \%$ of respondents who indicated they had been trained to give injections cited no specific method of training. This may be, in part, because no specific training methods were listed as choices. Respondents were asked to fill in a blank with their own training methods and some may have been reluctant to do so. With the large percentage (45\%) of respondents not citing a method of training for giving injections, there was risk in trying to ascertain if respondents were trained in giving injections according to BQA guidelines. The injection location results presented in Table 1 to 4 show that only 59 to $87 \%$ of respondents used the BQA-friendly neck region for s.c. and i.m. injections in cows and calves. The upper rear leg region, which is not a BQA-friendly injection location, was used for i.m. injections in cows and calves by 18 to $32 \%$ of respondents. These results suggest that efforts are needed to train, or retrain, dairy workers on recommended injection protocols and procedures to ensure that s.c and i.m. injections in cows and calves are given in a BQA-friendly manner.

The survey included questions focused on the importance of BQA on dairies and the effect that dairy animals have on the beef industry to ascertain views on their role and responsibilities to the beef industry. Survey respondents rated each of these items as being moderately important. Using a 5 -point scale $(0=$ low; 4 $=$ high), dairy producers rated the importance of BQA on dairies as 2.6. Similarly, the effect that dairy animals have on the beef industry was rated as 2.5 by dairy producers.

Respondents were asked if veterinarians were utilized for regular herd health checks. Ninety-six percent of large dairies indicated their use of veterinarians for routine herd health checks, followed by medium-sized (92\%) and small dairies (65\%). Dairies were asked to identify the individual responsible for determining the vaccination program. Most dairy vaccination needs were determined by owners or managers and veterinarians. On small dairies (68.3\%), the owner or manager played a greater role in identifying vaccination needs than on medium $(48.7 \%)$ and large $(43.4 \%)$ dairies. Survey results showed that herdsmen had a greater role in determining vaccination needs on large dairies versus medium-sized and small dairies. To get some idea of where dairy owners, managers, and workers seek advice for animal health product use, consider the study by Sawant et al. (2005). They found on Pennsylvania dairies that a veterinarian's advice was sought always $(32 \%)$, most of the time (38\%), and sometimes (9\%) before antibiotic administration.

The survey asked participants how they identified their animals. Dairies were allowed to choose all animal identification methods that were used in their operation

Table 3. Location of routine i.m. injections in calves on Idaho dairies

\begin{tabular}{lcccccc}
\hline Dairy size $^{1}$ & $\begin{array}{c}\text { Neck } \\
(\%)\end{array}$ & $\begin{array}{c}\text { Shoulder } \\
(\%)\end{array}$ & $\begin{array}{c}\text { Upper rear } \\
\text { leg }(\%)\end{array}$ & $\begin{array}{c}\text { Side or } \\
\text { ribs }(\%)\end{array}$ & $\begin{array}{c}\text { Lower rear } \\
\text { leg }(\%)\end{array}$ & $\begin{array}{c}\text { Tail-head } \\
(\%)\end{array}$ \\
\hline Small $(\mathrm{n}=139)$ & 59.0 & 9.4 & 29.5 & 0.7 & 7.2 & 10.8 \\
Medium $(\mathrm{n}=74)$ & 63.5 & 9.5 & 25.7 & 0.0 & 8.1 & 6.8 \\
Large $(\mathrm{n}=54)$ & 61.1 & 5.6 & 20.4 & 0.0 & 11.1 & 7.4 \\
\hline
\end{tabular}

${ }^{1}$ Small $=<201$ cows; medium $=201$ to 1,000 cows; large $=>1,000$ cows. 
Table 4. Location of routine s.c. injections in calves on Idaho dairies

\begin{tabular}{lcccccc}
\hline Dairy size $^{1}$ & $\begin{array}{c}\text { Neck } \\
(\%)\end{array}$ & $\begin{array}{c}\text { Shoulder } \\
(\%)\end{array}$ & $\begin{array}{c}\text { Upper rear } \\
\text { leg }(\%)\end{array}$ & $\begin{array}{c}\text { Side or } \\
\text { ribs }(\%)\end{array}$ & $\begin{array}{c}\text { Lower rear } \\
\text { leg }(\%)\end{array}$ & $\begin{array}{c}\text { Tail-head } \\
(\%)\end{array}$ \\
\hline Small $(\mathrm{n}=139)$ & 77.7 & 13.7 & 5.0 & 3.6 & 0.7 & 5.8 \\
Medium (n = 74) & 81.1 & 12.2 & 5.4 & 9.4 & 1.4 & 1.4 \\
Large $(\mathrm{n}=54)$ & 74.1 & 5.6 & 9.3 & 0.0 & 3.7 & 3.7 \\
\hline
\end{tabular}

${ }^{1}$ Small $=<201$ cows; medium $=201$ to 1,000 cows; large $=>1,000$ cows.

(Table 6). Plastic ear tags were the preferred method of identification. All large (100\%) dairies, and most medium (97.3\%) and small (84\%) dairies reported using plastic ear tags. The use of hot iron brands was $55.8 \%$ on large, $43.2 \%$ on medium-sized, and $42.4 \%$ on small dairies. Even though Idaho is a brand-law state, it does not mandate that animals be branded. Considering the amount of technology that is employed on dairies and the potential implementation of a national animal identification system that will likely use radio frequency electronic tags in combination with more traditional identification methods, the authors expected a relatively large number of dairies to have implemented electronic identification methods. But $<10 \%$ of dairies indicated using electronic identification for their cattle.

The current survey was conducted several months after the identification of the first US case of bovine spongiform encephalopathy (BSE). Participating dairies were asked if the discovery of BSE and the ban on downer cows being harvested would warrant changes in their management protocols. Almost two-thirds (60.8\%) of respondents indicated that these developments would cause no change in their management practices. Additionally, respondents were asked if the discovery of BSE would change their marketing protocols. A similar percentage of dairies $(69.2 \%)$ indicated no changes in marketing would be made.

For several years a great deal of effort has been expended to implement a national animal identification system in the United States. To assess dairy owners' and managers' feelings about a national animal identification system, participants were asked whether or not the United States should have such a system. Generally, 25 to $33 \%$ of survey participants stated they did not know if this type of system should be implemented. This suggests that many dairy owners and managers are unsure about what a national program would entail and, if implemented, what the benefits would be. Approximately one-half of the respondents from large (48\%) and medium-sized (49\%) and $32 \%$ of respondents from small dairies noted their support for a national animal identification system. The percentage of respondents favoring a national animal identification program that supported it being mandatory was low- est on small dairies (41\%) followed by large $(59 \%)$ and medium-sized $(69 \%)$ dairies.

Accurate record keeping is one of the requirements of BQA and is essential to maintaining an efficient and profitable dairy. The survey included a series of questions asking which animal health and production records were kept by each dairy, as well as the record format, and the length of time records were maintained. Ninety-three percent of small dairies, $99 \%$ of mediumsized dairies, and $100 \%$ of large dairies indicated that they maintained records (Table 7). Large dairies were more likely to maintain a wider variety of records. Animal identification (number and description), calf birth records, and cow records (health, reproduction, and lactation) were the types of records most commonly maintained by the dairies. Dairies indicated they were less likely to maintain feed records, product supplier names, or BQA program records (e.g., injection site maps, drug withdrawals, animal health product inventory).

The majority (58\%) of respondents from small dairies used some paper format to keep records (Table 7), compared with respondents at medium-sized and large dairies that used some type of computer-based record system (85 and 100\%, respectively). In the study by Payne et al. (1999), 35\% of California dairies used computers to maintain drug treatment records, and paper records were used by $71 \%$ of the dairies. Computer records were utilized to a greater extent than paper records ( 57 vs. $36 \%$ ) on New Mexico dairies (Rogers et al., 2004). In all dairy size classes (Table 8), 50 to $60 \%$ of respondents indicated they maintained records for at least 2 yr.

Table 5. Percentage of dairy workers trained to give injections on ID dairies

\begin{tabular}{lc}
\hline Dairy size $^{1}$ & Workers trained $(\%)$ \\
\hline Small $(\mathrm{n}=139)$ & $75.8^{\mathrm{a}}$ \\
Medium $(\mathrm{n}=74)$ & $85.7^{\mathrm{ab}}$ \\
Large $(\mathrm{n}=54)$ & $92.3^{\mathrm{b}}$ \\
\hline
\end{tabular}

${ }^{\mathrm{a}, \mathrm{b}}$ Values in columns with different superscripts differ $(P<0.05)$.

${ }^{1}$ Small $=<201$ cows; medium $=201$ to 1,000 cows; large $=>1,000$ cows. 
Table 6. Animal identification (ID) methods by dairy size for Idaho dairies

\begin{tabular}{|c|c|c|c|c|c|c|c|c|c|}
\hline Dairy size ${ }^{1}$ & $\begin{array}{c}\text { Plastic ear } \\
\text { tag }(\%)\end{array}$ & $\begin{array}{c}\text { Hot iron } \\
\text { brand }(\%)\end{array}$ & $\begin{array}{c}\text { Metal ear } \\
\operatorname{tag}(\%)\end{array}$ & $\begin{array}{c}\text { Ear tattoo } \\
(\%)\end{array}$ & $\begin{array}{c}\text { Other } \\
(\%)\end{array}$ & $\begin{array}{c}\text { EID } \operatorname{tag}^{2} \\
(\%)\end{array}$ & $\begin{array}{c}\text { Freeze } \\
\text { brand }(\%)\end{array}$ & $\begin{array}{c}\text { Ear notch } \\
(\%)\end{array}$ & $\begin{array}{c}\text { No ID } \\
(\%)\end{array}$ \\
\hline Small & 84.0 & 42.4 & 23.0 & 18.8 & 11.8 & 2.1 & 4.9 & 5.6 & 4.9 \\
\hline Medium $(\mathrm{n}=74)$ & 97.3 & 43.2 & 32.4 & 23.0 & 2.7 & 5.4 & 2.7 & 5.4 & 0.0 \\
\hline
\end{tabular}

${ }^{1}$ Small $=<201$ cows; medium $=201$ to 1,000 cows; large $=>1,000$ cows.

${ }^{2} \mathrm{EID}=$ electronic identification.

Dairy cows are culled from the herd for a variety of reasons. Survey respondents were asked to provide the percentage of cows marketed each year for several culling factors. The average percentage of cows leaving the herd due to reproductive problems was $30 \%$, followed by low milk production $(28 \%)$, mastitis $(25 \%)$, health concerns (14\%), and feet and leg problems (13\%). These numbers are very similar to those reported by Rogers et al. (2004), where New Mexico dairy producers reported low milk yield (31\%), reproductive failures (25\%), chronic mastitis (13\%), deteriorating locomotion (9\%), and other health problems $(8 \%)$ as the predominant reasons for cows leaving the herd. The most frequent reason for cows leaving Pennsylvania dairy herds was injury and lameness (35.9\%; Tozer et al., 2005).

One section of the survey inquired about the cull cow and calf marketing methods employed by Idaho dairies. The marketing questions offered auction market, order buyer, forward contract, and private treaty as marketing options for cull cows and calves. An additional marketing option listed for cull cows was direct market to the packer. Survey participants were asked to select any or all of the marketing options used by their dairy to determine which marketing methods were most used by dairies. As dairies marketed their cull cows, they used auction markets most often (64\%), followed by order buyers $(17 \%)$, direct to the packer $(17 \%)$, private treaty sales (16\%), and forward contract (1\%). Idaho dairies preferred auction markets over other outlets. This may be due in part to the limited number of packing plants harvesting market cows in the area. Payne et al. (1999) found that $22 \%$ of California dairies marketed cows directly to a packing plant. Rogers et al. (2004) found that respondents preferred to sell market cows to both auctions and packing plants. Forty percent of the New Mexico dairies preferred to sell market cows to auctions only, and $10 \%$ of the dairies preferred to use the packing plant exclusively.

As the market cow marketing selections were compiled based on dairy size, large dairies used auction markets most often $(62 \%)$, followed by order buyers $(33 \%)$, private treaty sales $(23 \%)$, and direct to the packer $(23 \%)$. Medium-sized dairies favored auction markets $(61 \%)$ over direct to the packer $(17 \%)$, private treaty sales (15\%), and order buyers (14\%) when selling market cows. Small dairies chose auction markets $(66 \%)$ to sell their market cows more often than direct to the packer $(15 \%)$, private treaty sales $(14 \%)$, and order buyers $(13 \%)$.

The most-used calf (bulls and heifers combined) marketing method was private treaty sales $(52 \%)$, followed by auction markets (42\%), order buyers (14\%), and forward contracts (1\%). Regardless of size, dairies chose private treaty sales over auction markets, order buyers, and forward contracts to market their calves.

\section{CONCLUSIONS}

This study provides important information about Idaho dairy demographics, dairy management and marketing practices, as well as valuable insight of basic BQA practices. At the time of initiation of the survey, Idaho did not have a formal dairy BQA program. The results of the survey are currently being used by extension personnel to plan new dairy BQA training curricula targeting dairy owners, managers, and em-

Table 7. Farm record format by dairy size for Idaho dairies

\begin{tabular}{lcccccc}
\hline Dairy size $^{1}$ & $\begin{array}{c}\text { None } \\
(\%)\end{array}$ & $\begin{array}{c}\text { Paper } \\
(\%)\end{array}$ & $\begin{array}{c}\text { Commercial } \\
\text { software }(\%)\end{array}$ & $\begin{array}{c}\text { Other software } \\
(\%)\end{array}$ & $\begin{array}{c}\text { Paper and } \\
\text { software }(\%)\end{array}$ & $\begin{array}{c}\text { Other } \\
(\%)\end{array}$ \\
\hline Small $(\mathrm{n}=139)$ & 6.9 & 58.3 & 14.6 & 4.9 & 13.9 & 1.3 \\
Medium $(\mathrm{n}=74)$ & 1.4 & 13.5 & 60.8 & 6.8 & 12.2 & 5.4 \\
Large $(\mathrm{n}=54)$ & 0.0 & 0.0 & 83.0 & 0.0 & 17.0 & 0.0 \\
\hline
\end{tabular}

${ }^{1}$ Small $=<201$ cows; medium $=201$ to 1,000 cows; large $=>1,000$ cows. 
Table 8. Length of time farm records are maintained by dairy size for Idaho dairies

\begin{tabular}{|c|c|c|c|c|c|}
\hline Dairy size $^{1}$ & $\begin{array}{l}\text { Do not save } \\
\text { records }(\%)\end{array}$ & $\begin{array}{l}\text { Save records until } \\
\text { sale of animals (\%) }\end{array}$ & $\begin{array}{l}\text { Save records } 1 \text { yr } \\
\text { post-sale }(\%)\end{array}$ & $\begin{array}{l}\text { Save records } 2 \text { yr } \\
\text { post-sale }(\%)\end{array}$ & $\begin{array}{l}\text { Save records }>2 \\
\text { yr post-sale }(\%)\end{array}$ \\
\hline Small $(\mathrm{n}=139)$ & 9.9 & 26.8 & 9.9 & 7.0 & 46.5 \\
\hline Medium $(\mathrm{n}=74)$ & 5.6 & 25.0 & 11.1 & 5.6 & 52.8 \\
\hline
\end{tabular}

${ }^{1}$ Small $=<201$ cows; medium $=201$ to 1,000 cows; large $=>1,000$ cows.

ployees. Future studies are needed to assess whether the self-reported results described in this survey coincide with actual compliance or implementation on dairies.

\section{ACKNOWLEDGMENTS}

The authors acknowledge the Idaho Dairymen's Association for financial support of this project, and the University of Idaho Social Science Research Unit for assistance with data analysis and interpretation. Additionally, the authors acknowledge the dairy producers of Idaho for responding to the survey.

\section{REFERENCES}

Buttars, N. K., A. J. Young, and D. Bailey. 2006. Adoption of security systems by dairy farms to address bioterrorist threats in the Intermountain United States. J. Dairy Sci. 89:1822-1829.

Dillman, D. 1978. Mail and telephone surveys. John Wiley \& Sons, New York, NY.

Payne, M., C. M. Bruhn, B. Reed, A. Scearce, and J. O'Donnell. 1999. On-farm quality assurance programs: A survey of producer and industry leader opinions. J. Dairy Sci. 82:2224-2230.
Roeber, D. L., K. E. Belk, G. C. Smith, J. D. Tatum, T. G. Field, J. A. Scanga, C. D. Smith, P. D. Mies, H. A. Foster, T. K. Kennedy, B. R. Moore, and S. G. Hodge. 2000. Improving the consistency and competitiveness of market cow and bull beef and improving the value of market cows and bulls. Final Report of the National Market Cow and Bull Beef Quality Audit- 1999. National Cattlemen's Beef Association, Englewood, CO.

Rogers, C. A., A. C. Fitzgerald, M. A. Carr, B. R. Covey, J. D Thomas, and M. L. Looper. 2004. On-farm management decisions to improve beef quality on market dairy cows. J. Dairy Sci. $87: 1558-1564$

Sawant, A. A., L. M. Sordillo, and B. M. Jayarao. 2005. A survey on antibiotic usage in dairy herds in Pennsylvania. J. Dairy Sci. 88:2991-2999.

Smith, G. C., J. B. Morgan, J. D. Tatum, C. C. Kukay, M. T. Smith, T. D. Schnell, and G. G. Hilton. 1994. Improving the consistency and competitiveness of non-fed beef; and, improving the salvage value of cull cow and bulls. Final Report of the National NonFed Beef Quality Audit. National Cattlemen's Beef Association, Englewood, CO.

Tozer, P. R., G. A. Varga, W. R. Henning, and L. A. Holden. 2005. Do dairy producers use effective management practices to improve the value of market cows? Prof. Anim. Sci. 21:272-277.

USDA-NASS. 2006. Idaho Agricultural Statistics. USDA, Boise, ID. 